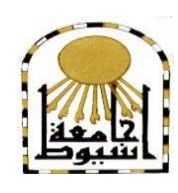

\title{
كلية التربية
}

كلية معتمدة من الهيئة القومية لضمان جودة التعليم

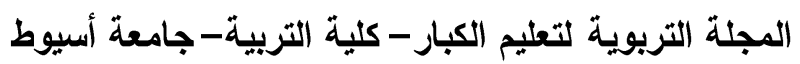

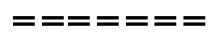

\section{هموقات التـمكين الإداري لقيادات التمايم الثانوي وسبل التغخاب عابدها}

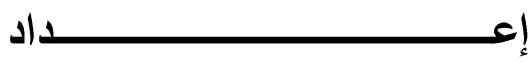

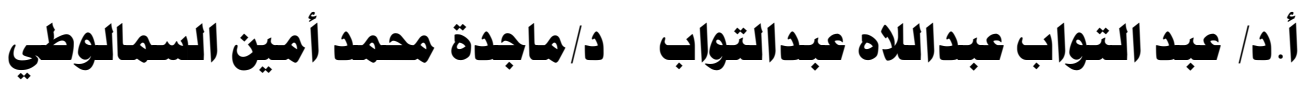

استاذ أصول التربية المتفرغ

كلية التربية - جامعة أسيوط
أستاذ أصول التربية المتفرغ

عميا كلية التربية الأسبق

كلية التربية جامعة أسيوط

\section{الباحثة/ وفاء أهمد عبد الفتاح عاهر}

باحثة دكتوراه أصول التربية - كلية التربية - جامعة أسيوط

$$
\text { |) (المجلد الثانى - العدد الثالث - يوليو ، r . rم ) }
$$

Adult_EducationAUN@aun.edu.eg 
معوقات التمكين الإداري لقيادات التعليم الثاتوي

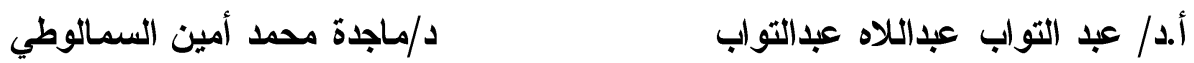

أل وفاء أحمد عبد الفتاح عامر

$=\frac{\pi}{r}$

$: \ddot{a}$

مقدم - مقر

تشكل الإدارة في رأي العديد من الباحثين عنصرا مهما في نجاح العملية التعليمية

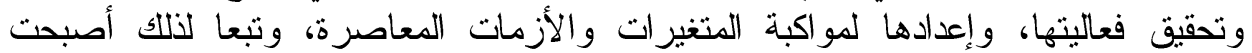

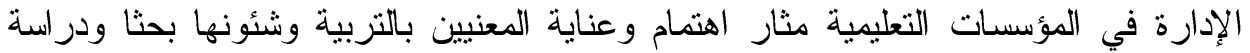
للوصول بها إلى أعلى قدر من الكفاءة المطلوبة لإنجاز ما يناط بها من مهام ومسئوليات. ويعد التككين من أهم العناصر التي تقف وراء أداء العاملين، فهو يضمن تكافؤ

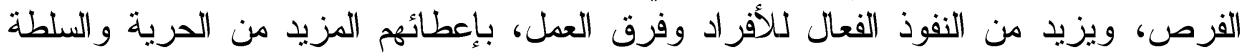

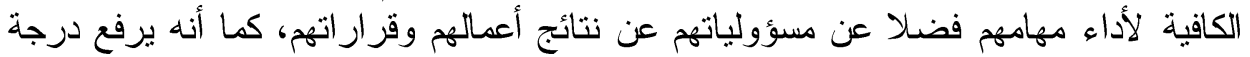

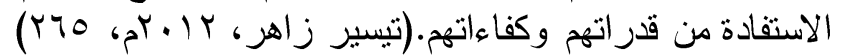

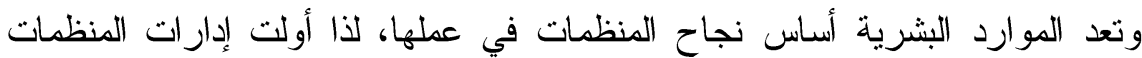

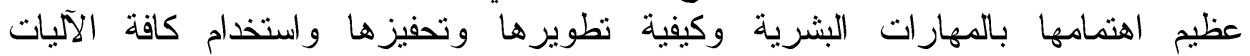

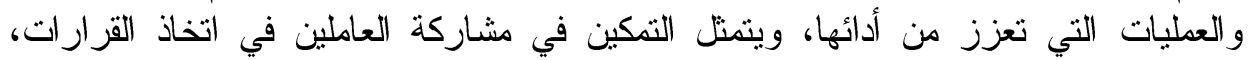

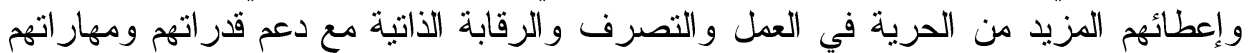

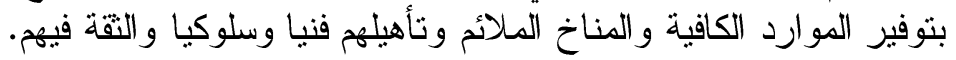

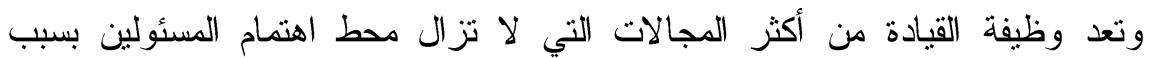

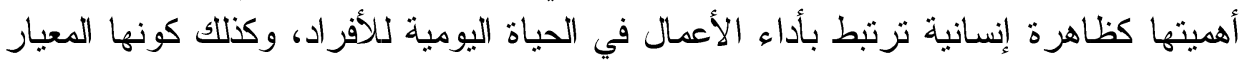

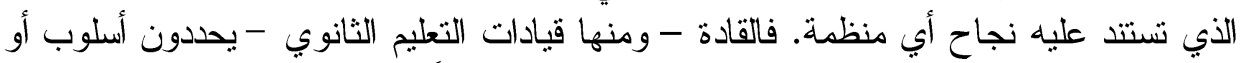
مدخل التعامل مع المشاكل ويتخذون القرارات، ويتبنون قيماً معينة ويحددون الإستراتيجيات،

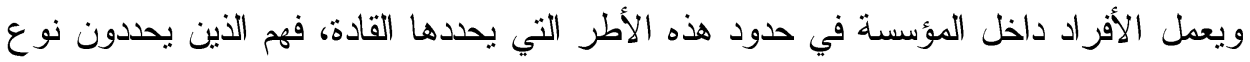

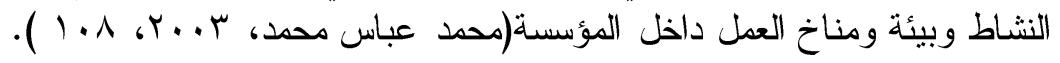
ويعتبر التمكين الإداري من المداخل الإدارية التي تلجأ إليها الإدارات؛ لتزويد العاملين

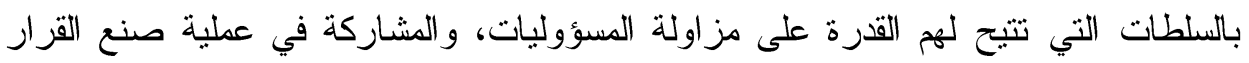

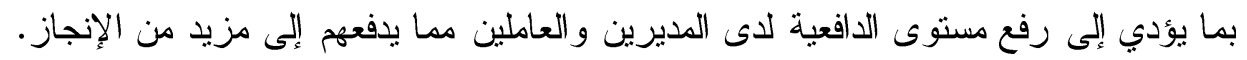
ونجاح برامج التمكين الإداري تتطلب بالدرجة الأولى اقتناع الإدارة بفلسفة التمكين

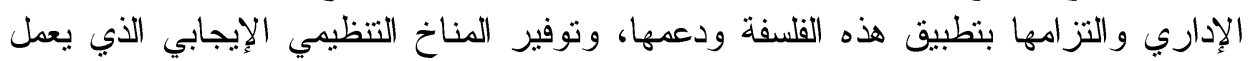

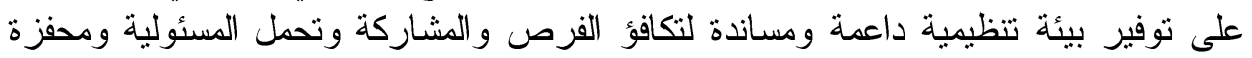
لتطوير أساليب العمل وتحسين الأداء. تلظئ. داعثة 


\section{المجلة التربوية لتعليم الكبار - كلية التربية - جامعة أسيوط}

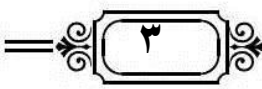

يتضح مما سبق أن التمكين الإداري لقيادات التعليم الثانوي يسهم فى تحسين أدائهم،

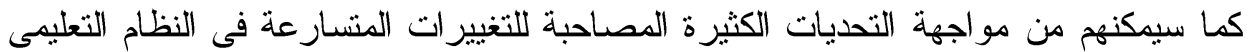
و البيئة المحيطة بهم والاستجابة لدواعى التطوير التربوى.

\section{مشكلة الار اسة:}

تعتبر دراسة التمكين الإداري من الموضوعات الإدارية الحديثة التي نالت اهتمام الباحثين في مجال الادارة المدرسية المدرسية لأن أدبيات التمكين الإدارى تثميز بالثين لإنمولية

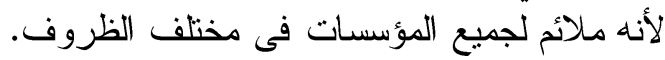

فالهدف الرئيس للتمكين الإداري هو تعزيز دور القيادات التربوية؛ لتكون فاعلة فى لئ

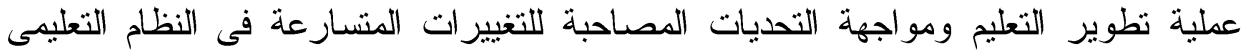
و البيئة المحيطة. فهو الأساس الذى يمكن المدير من ممارسة سلطته بأكمل وجه، ويشكل احدى الدعائم الأساسية التى تقوم عليها المدرسة لمواجهة التطورات و التحديات المعاصرة.

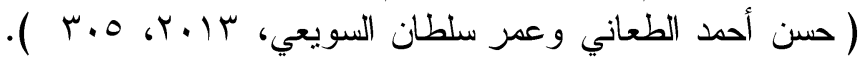

وأصبح أساس تقدم أى شعب من الثعوب فى العالم المعاصر يقاس بمدى تقدم المؤسسات التعليمية الموجودة فيه، ومدى تقدم ونجاح هذه المؤسسات يقاس بنوعية وكفاءة

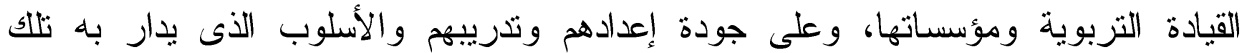

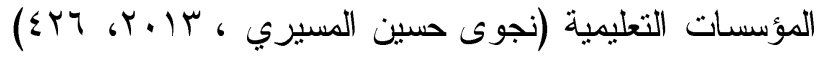

وبناءً على ذلك أصبح من الضرورى تطوير إدارة المدرسة الثانوية العامة لتكون

قادرة فى وجود مناخ فعال تعمل فيه على مواكبة العصر الحالى، حيث أن فقدان التكامل بين مدير المدرسة والهيكل التتظيمى القائم من ناحية، وبينه وبين المجتمع المحلى من ناحية

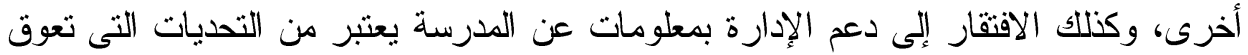

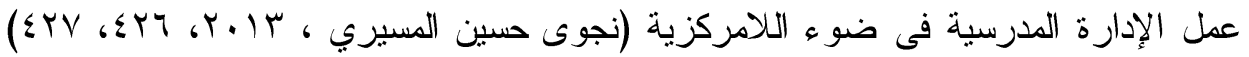

ومن خلال اطلاع الباحثة على العديد من الدراسات العربية والاجنبية التي

تتاولت واقع التمكين الإداري، وجدت الباحثة ان المشكلة التي تواجه قيادات التعليم

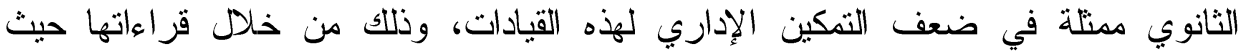
وجدت تعدد الدراسات العربية والأجنبية التي تناولت واقدي لهاده التمكين الإداري؛ كدراسة:

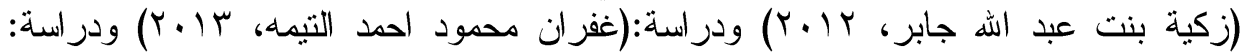

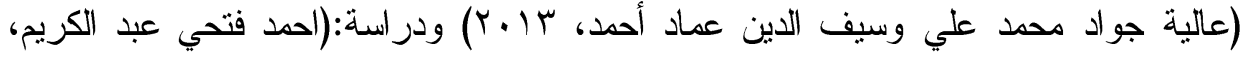


معوقات التمكين الإداري لقيادات التعليم الثاتوي

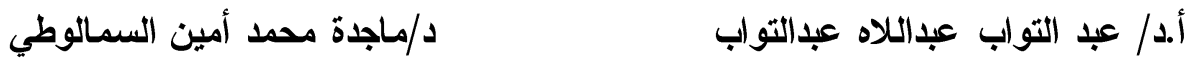

أ/ وفاء أحمد عبد الفتاح عامر

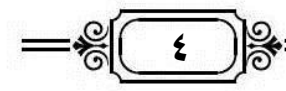

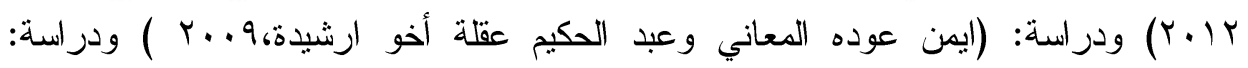

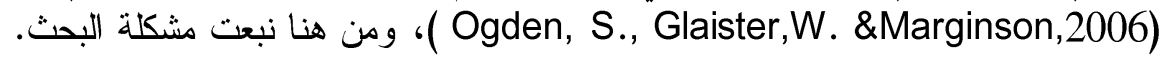

لأ يمكن تحليد مشكلة الاراسة في التساؤل الرئيس التالي" ما معوقات التمكين

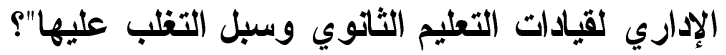

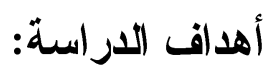

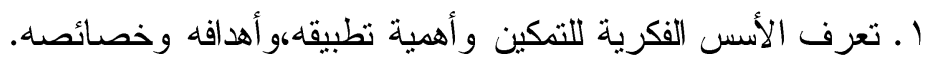

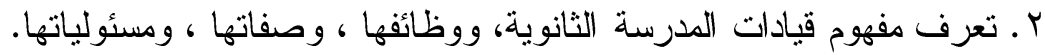
r. ب. بيان معوقات التمكين الإداري لقيادات التعليم الثانوي.

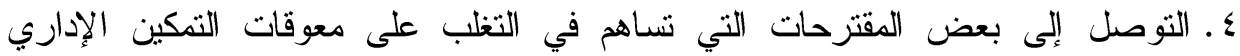
لقيادات التعليم الثانوي.

أهمية الار اسة:

- الأهمية النظرية: ترجع في تتاولها للتكين الإداري وأبعاده، وخصائصه،، وأهميته؛

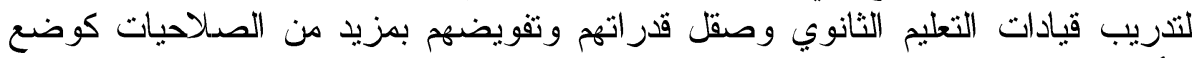

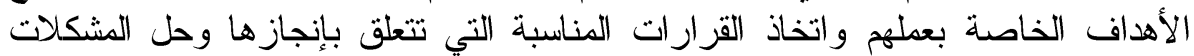
التي تعوق تحقيقها؛ وذلك للتغلب على المعوقات.

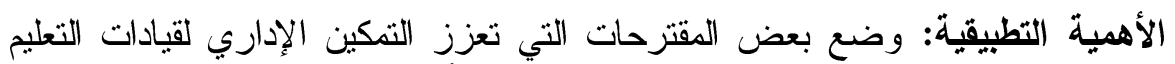

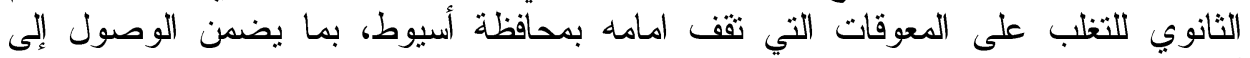
أفضل النتائج.

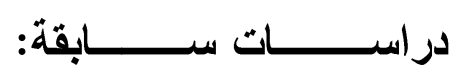

أولا: دراسات عربية: دراسة: (اخلاص إبراهيم الطراونة وسميرة محمد مبارك

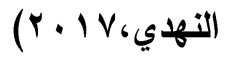

هدفت الدراسة إلى التعرف على واقع ومستوى التمكين الإدارى ومستوى المهارات

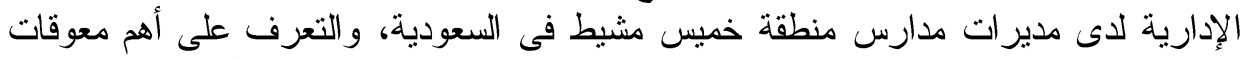

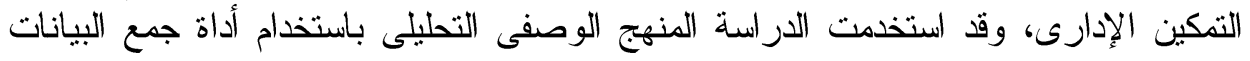

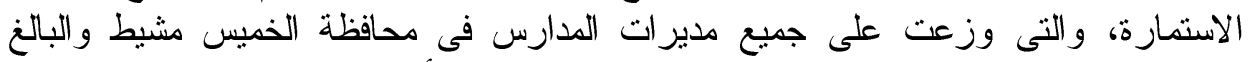
عددهن (1N1) مديرة كعينة مسح شامل، وقد استخدمت الأساليب الإحصائية لتحليل نتائج 


\section{المجلة التربوية لتعليم الكبار - كلية التربية -جامعة أسيوط}

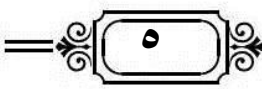

الدراسة والتى أثنارت إلى: أن التمكين الإدارى متاح لمديرات المدارس بدرجة متوسطة.

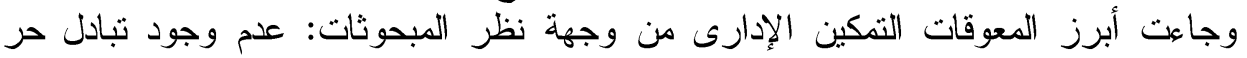

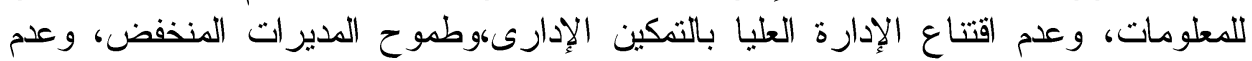
وجود تذريب على اتخاذ القرار .

دراسة: (أحمد فتحي عبد الكريم، ب ا ب ץ):هدفت الدراسة تعرف درجة التمكين الإداري لدى القيادات التربوية في وزارة التربية والتعليم في المملكة العربية السعودية من وجهة نظر المنتسبين لدورة مديري المدارس والمشرفين التربويين في جامعتي الملك سعود و الإمام محمد بن سعود الإسلامية في الرياض، وبلغ عدد افراد الدراسة (10 (1) فردا منهم

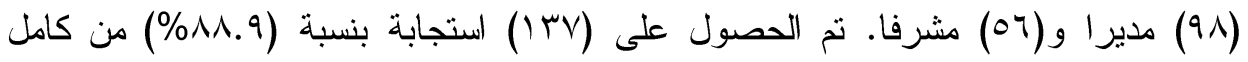
أفراد الدراسة. ولتحليل البيانات تم استخراج التكرارات والمتوسطات الحسابية والانحرافات المعيارية، وتحليل التباين الأحادي، وتحليل التباين المتعدد، ونتائج اختبار شيفييه للمقارنات البعدية، وتعددت نتائج الدراسة وكان من أهمها وجود فروق ذات دلالة إحصائية بين المتوسطات الحسابية لدرجة التمكين الإداري الممنوحة من قبل القيادات التربوية تعزى لمتغير العمل الحالي لاى المستجيبين ولصالح المشرفين التربويين، وعدم وجود فروق ذات دلالة إحصائية بين المتوسطات الحسابية لدرجة التمكين الإداري الممنوحة من قبل القيادات التربوية تعزى لمتغير المؤهل العلمي، وعدد سنوات الخبرة لاى المستجيبين.

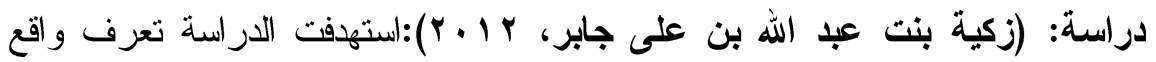
التمكين الإداري لمديرات المدارس الثانوية في منطفة جدة التعليمية، وتحديد أهم معوقات وفوائد تمكينهن، و استخدمت الباحثة مقياس لواقع التمكين الإداري لمديرات المدارس الثانوية، ومعوقاته وفوائده، وبلغت عينة الدراسة (1/1) مديرة ومشرفة تربوية، وتوصلت الدراسة لعدة نتائج من بينها: توجد فروق ذات دلالة إحصائية بين متوسطات استجابات مديرات المدارس لواقع التمكين الإداري للمديرات في أبعاد: (تفويض السلطة والصدلاحيات، وتتمية روح الفريق، والاتصال وتدفق المعلومات، وتدريب الموارد البثرية، والمكانة)، وفقا لعدد سنوات الخبرة، وجاءت الفروق لصآح المديرات كثيرات الخبرة.

دراسة: (أيمن عوده المعاني وعبد الحكيم عقلة أخو ارشيدة، 9 ه . ب):تهدف هذه الدراسة تعرف تصورات العاملين في الجامعة الأردنية نحو مفهوم التمكين الإداري، وأثز ذلك في إبداعهم الإداري، واختبار الفروق في تلك التصورات تبعا لاختلاف خصائصهم 
معوقات التمكين الإداري لقيادات التعليم الثاتوي

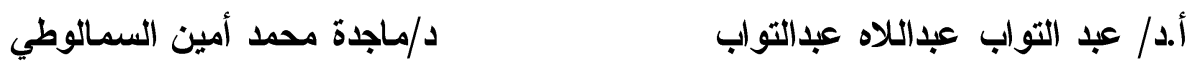

أ/ وفاء أحمد عبد الفتاح عامر

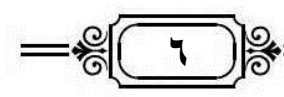

الديموغر افية والوظيفية. شملت الدراسة عينة عشوائية بلغت (90) موظفا من العاملين في

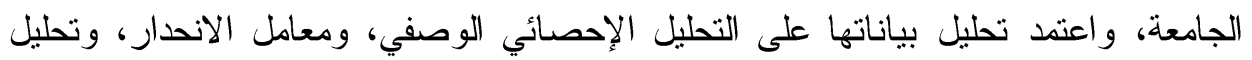

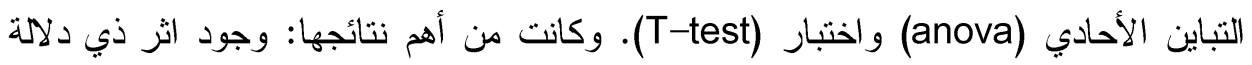

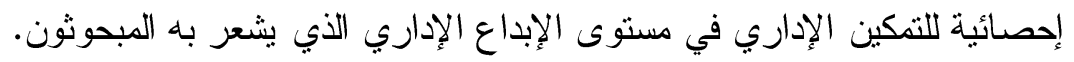

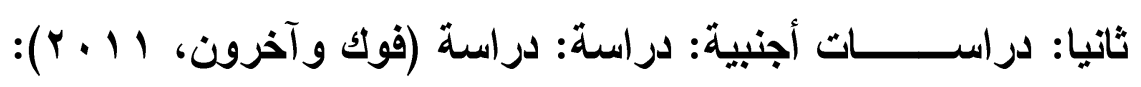

والتى هدفت إلى دراسة العلاقة بين الثقافة المدرسية والصحة التنظيمية المدرسية و التمكين النفسى لدى مدراء المدارس الثانوية فى ماليزيا وقد استخدم الباحثون الاستبيان

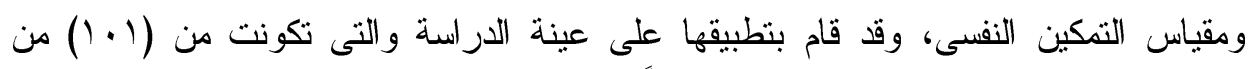

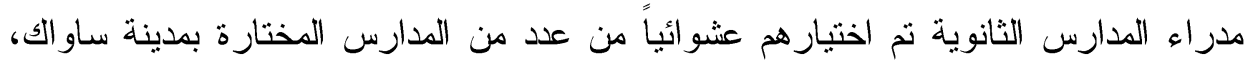

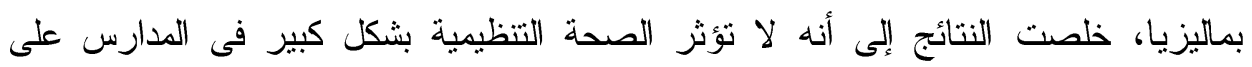

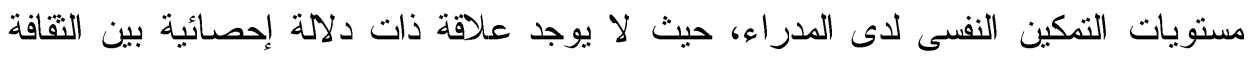

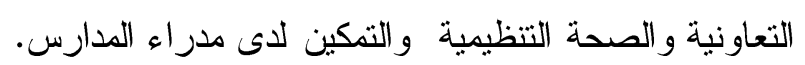

التعليق على الدراسات السابقة: تتاولت العديد من الدراسات السابقة التمكين

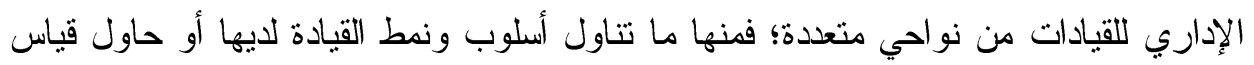

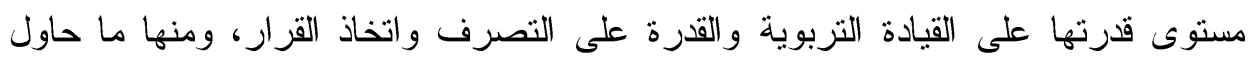

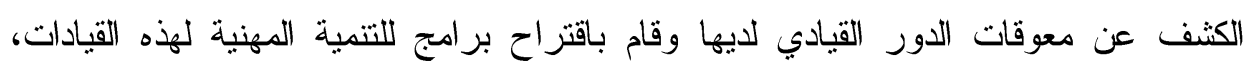
وتختلف الدراسة الحالية عن الدراسات السابقة في محاولة الكشف عن معوقات التمكين الإداري لقيادات التعليم الثانوي في محافظة أسيوط، وسبل التغلب عليها.

\section{تساؤلات الارارسة :}

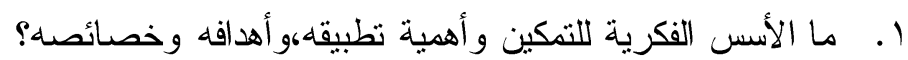

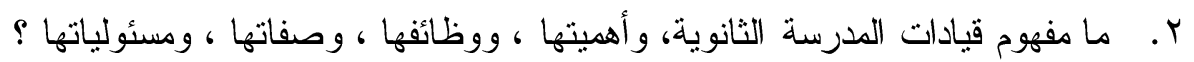

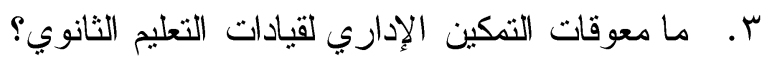

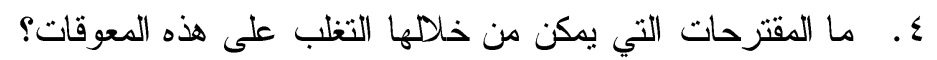


استخدمت الباحثة المنهج الوصفي باعتباره أقرب المناهج العلمية لدراسة المشكلة،

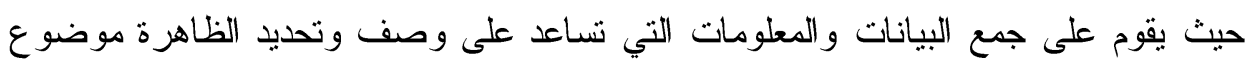
الدر اسة وتحليلها و تقسير ها. مصطلحات الار اسةة:

التمكين الإداري: إستراتيجية تنظيمية تهاف إلى تحقيق تكافؤ الفرص و إعطاء

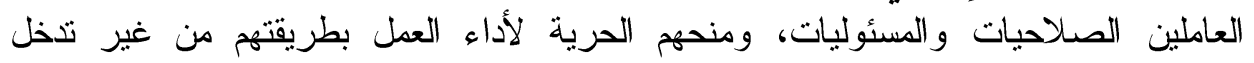

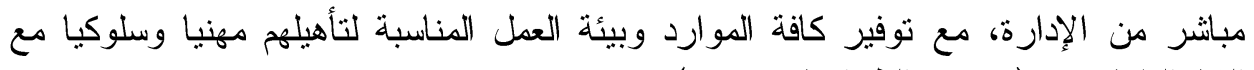

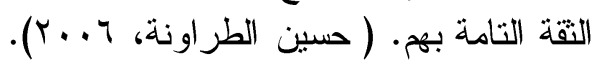
قيادات التعليم الثانوي: عرفت بأنها القدرة على رئاسة جمع من العاملين وقيادتهم

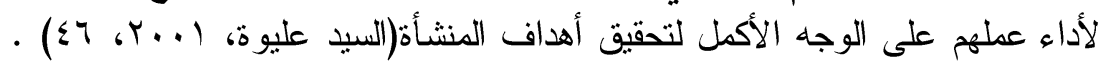

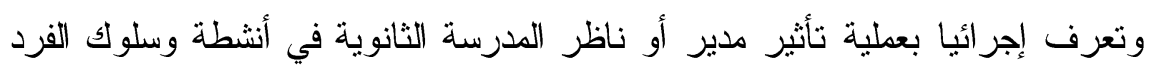

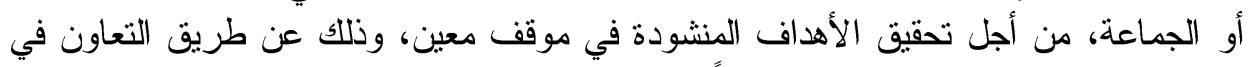

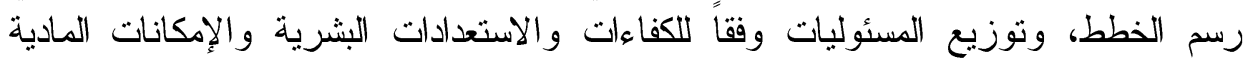
المتاحة في مرحلة التعليم الثانوي.

$$
\text { إجراءات الأر استة: }
$$

للإجابة عن تساؤلات للار اسة قامت الباحثة بالإطلاع على الأدبيات والدراسات السابقة

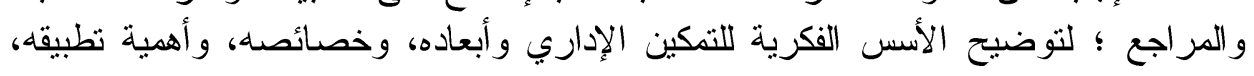

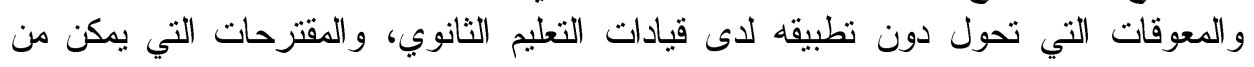
خلالها التغلب على هذه المعوقات. وقد تتاولت الباحثة بالعرض والتحليل التأصيل النظري لموضوع التمكين الإداري،

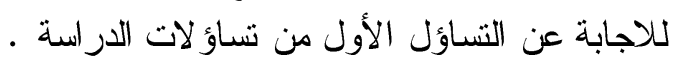
المحور الأول: الأسس الفكرية للتمكين الإداري:

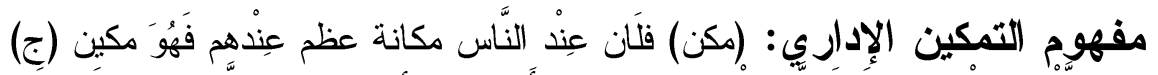

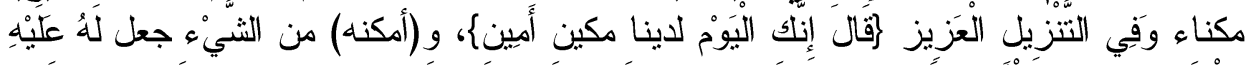

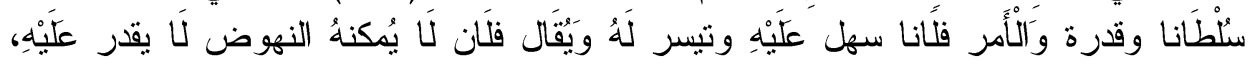


معوقات التمكين الإداري لقيادات التعليم الثاتوي

أ.د/ عبد التواب عبداللاه عبدالتواب

أ/ وفاء أحمد عبد الفتاح عامر

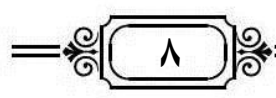

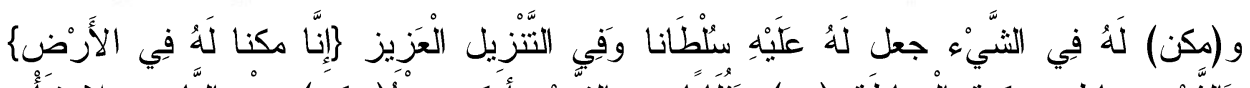

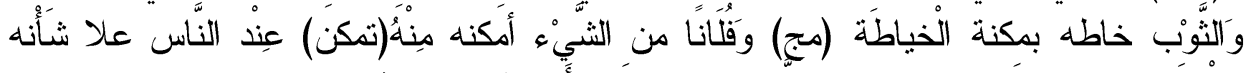

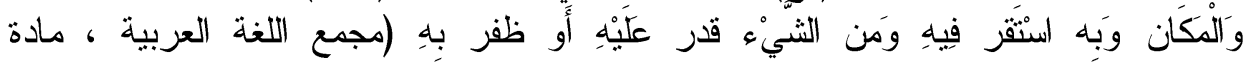

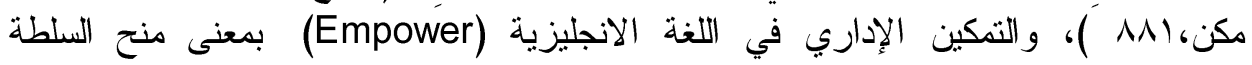

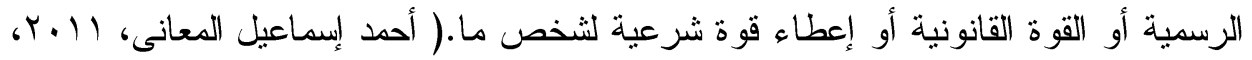

واصطلاحا: إستراتيجية تنظيمية تهدف إلى تحقيق تكافؤ الفرص و إعطاء العاملين

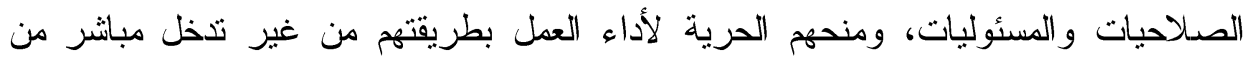

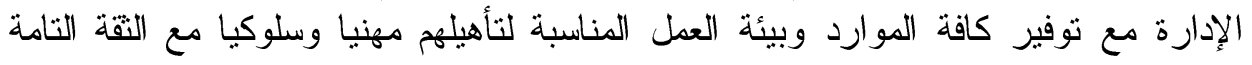

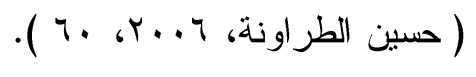

يتبين مما سبق أن التككين الإداري إستراتيجية إدارية تسعى لحث المرؤوسين

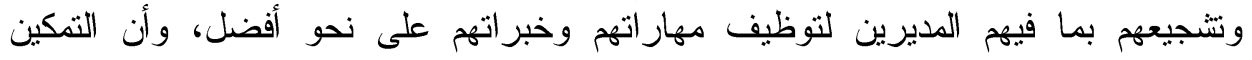

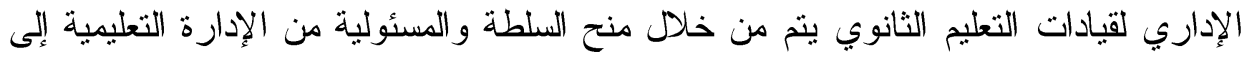

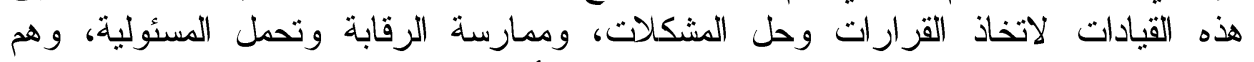

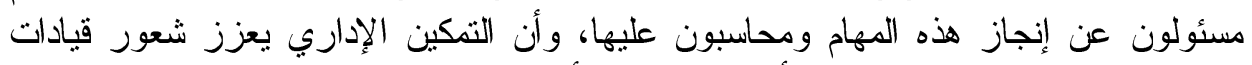

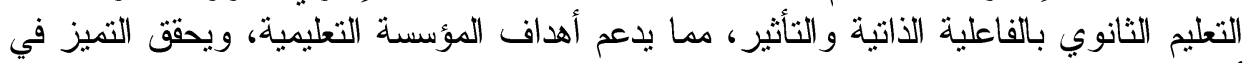
أدائها.

أهمية التمكين الإداري: يساعد التمكين قيادات التعليم الثانوي على تحقيق الميزة

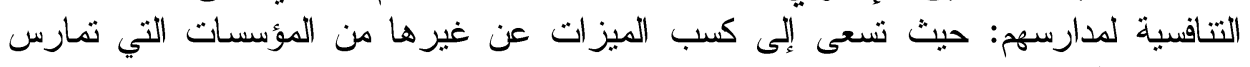
نفس النشاط.

وكنلك بساهم التمكين الإداري في تحقيق الرضا الوظيفي لقيادات التعليم الثانوي:

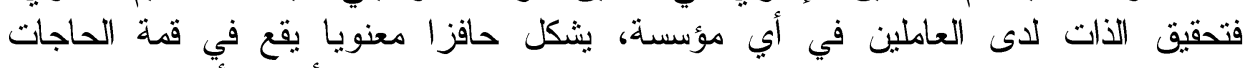

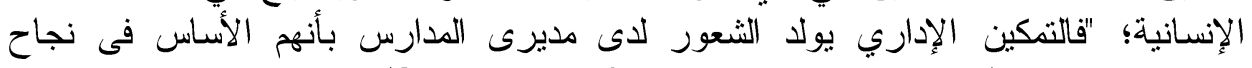

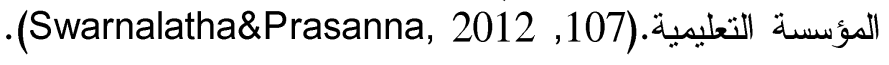
كما أن التمكين الإداري يزيد من قدرات قيادات التعليم الثانوي على الابتكار والإبداع

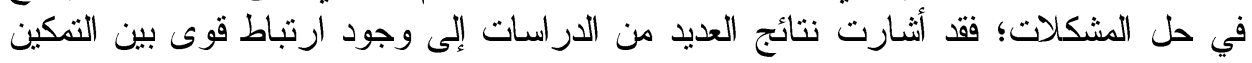

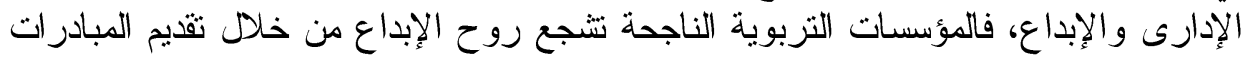




\section{المجلة التربوية لتعليم الكبار - كلية التربية - جامعة أسيوط}

$=\frac{9}{9}$

وتتجيع الافكار الجديدة: "والمؤسسات التى تمنح المرؤوسين الفرص لممارسة السلطة وللتعلم

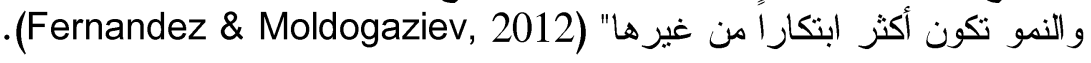

"فالإبداع فى العمل التعليمي يحتاج إلى توفير التمكين الإداري لمديرى المدارس، لأن

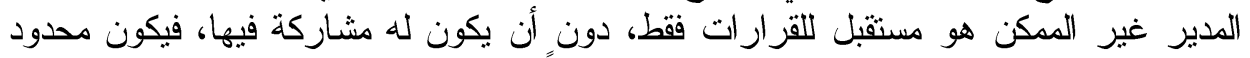

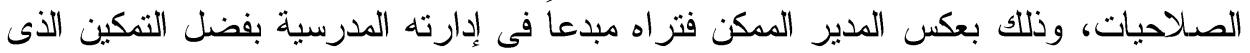

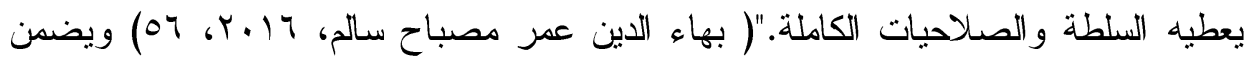
وصول مقترحاته وأفكاره إلى متخذي القرار، وعدم وضع هذه الأفكار في الطريق الطويل للمستويات الإدارية الهرمية الكبيرة في الارتفاع، و والمعوقة للإبداع و الابنكار.

وتجدر الإشارة هنا إلى ان أهمية التمكين الإداري تكمن في تتميته المهارات القيادية

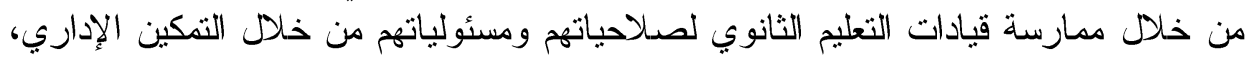
مما يجعلهم أكثر استقلالية في إدارة مهامهم، وتدفعهم إلى اكتشاف الموادي اهب والقدرات القيادية

لاى مرؤوسيهم.

أهداف التمكين الإداري: تمنل الأهداف مجموعة النتائج النهائية التي تسعى أي

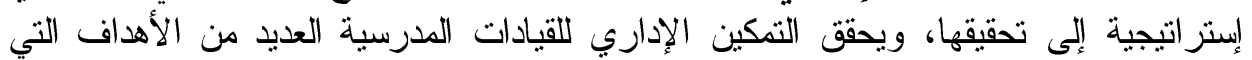
تساعد المؤسسة التعليمية على أداء أدوارها على على الوجها الألى الأدمل.

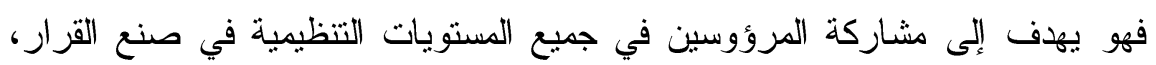

و التزام الرؤساء بمساعدة المرؤوسين على تحقيق الذات ( جمال محمد علي ، 9 ، . بام، 110

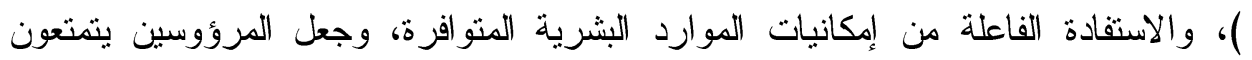
برضا أعلى تجاه وظائفه ومؤسساتهم، ومن ثم الوصول إلى أفضل أداء لهم.( زكريا مطلك وجن

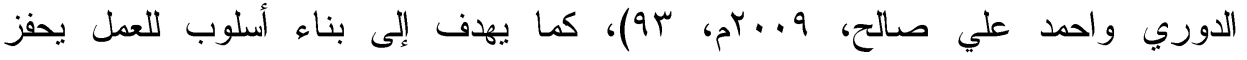
المرؤوسين داخليا كشعور هم بالانتماء والاعتز از بممارسة العمل في المؤسسة. ويمكن القول أن الهدف الرئيس للتمكين الإداري لقيادات التعليم الثانوي يتمثل في الاستفادة من قدراتهم لتحسين وتطوير العملية التعليمية.

خصائص الأمكين الإداري: للتمكين الإداري خصائص تميزه، وفيما يلي بعض

هذه الخصائص:

- التمكين الإداري متعدد الأشكال ويتحقق بعدة وسائل منها تفويض السلطات و المشاركة في

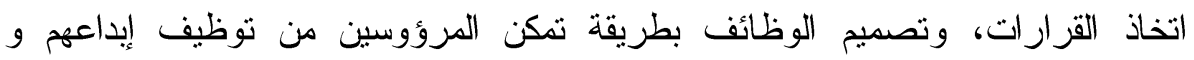


معوقات التمكين الإداري لقيادات التعليم الثاتوي

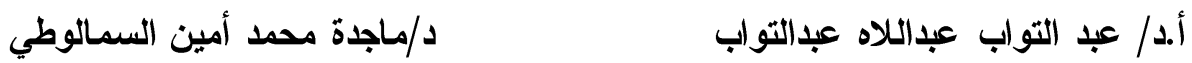

أز وفاء أحمد عبد الفتاح عامر

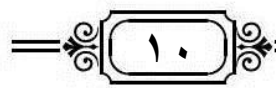

و التتافس والطموح المستمر، لتحقيق الانجازات والأهداف (رامي جمال أندراوس وعادل

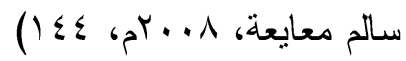

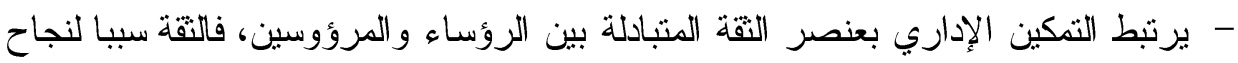

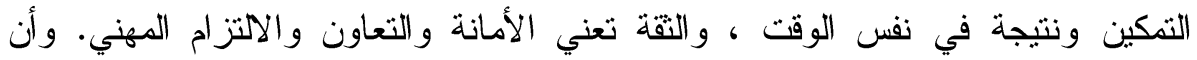

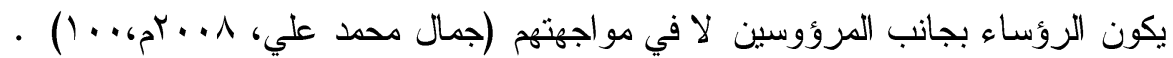

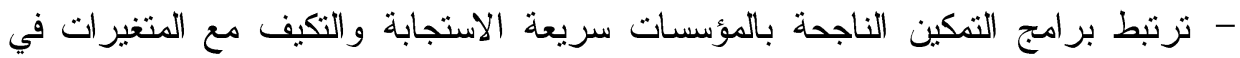
البيئة المحيطة بالمؤسسة، وهي المؤسسات التي تتبنى هياكل تتظيمية غير تقليدية،

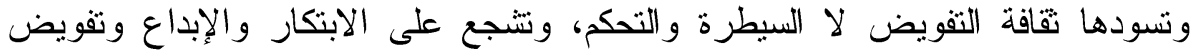

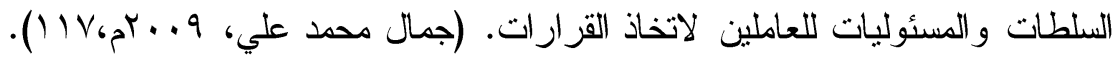

\section{المحور الثاني: قيادات المدرسة الثانوية :}

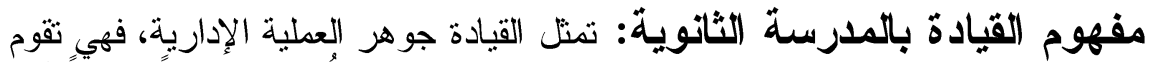

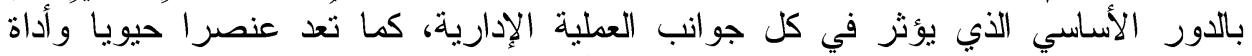

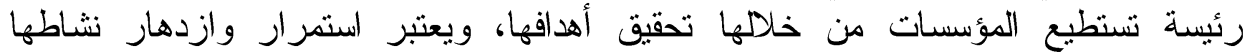

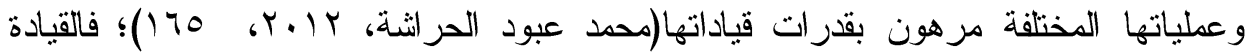
الناجحة حجر الزاوية في العملية التعليمية التزبوية فهي التي تحدد المعالم وترسم الطرية التريقة

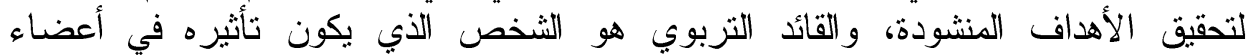

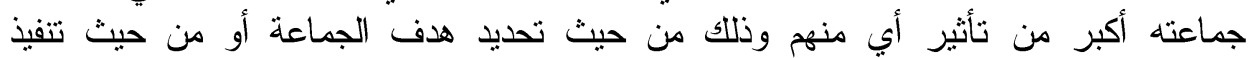

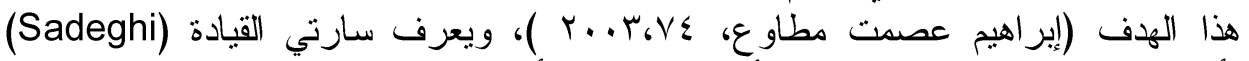

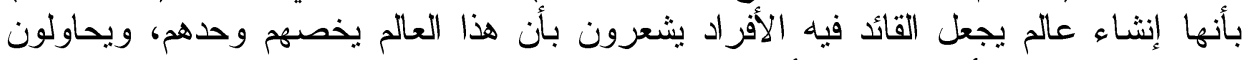
بذل كل طاقتهم من أجل تحقيق الأهداف المنشودة (Sadeghi,2013,172).

فالقيادة عملية التأثير في أنشطة وسلوك الفرد أو الجماعة من أجل تحقيق الأهداف

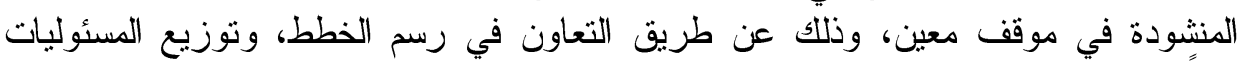
وفقاً للكفاءات والأستعدادات البشرية، والإمكانات المادية المتاحة في مرحلة التعليم الثانوي.

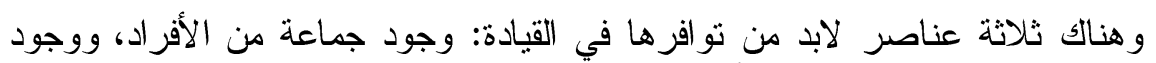

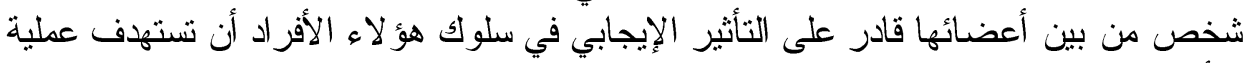

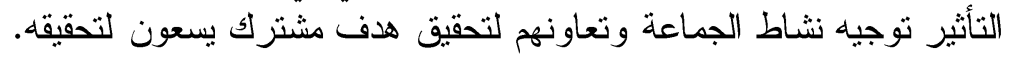




\section{المجلة التربوية لتعليم الكبار - كلية التربية -جامعة أسيوط}

$=\frac{\pi}{11}$

أهمية القيادة: تكمن أهمية القيادة في أنها حلقة الوصل بين العاملين وبين خطط

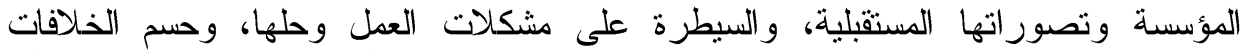

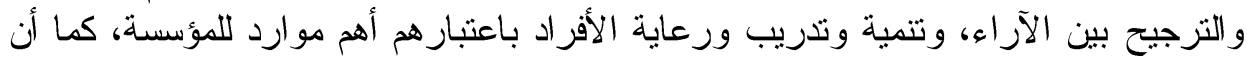

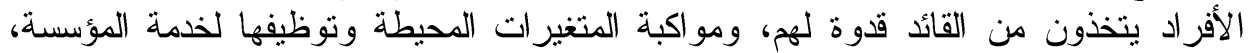

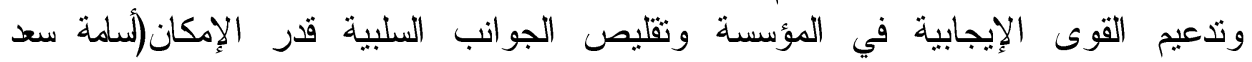

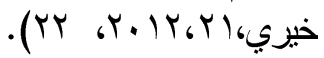

وتمثل القيادة المحرك الرئيس في حياة الأفر اد و الأمم و الثتعوب، فهي ظاهرة اجتماعية نلمس فئس

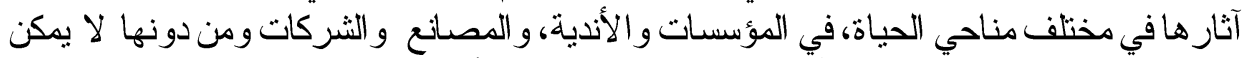

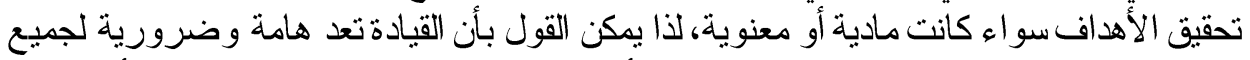

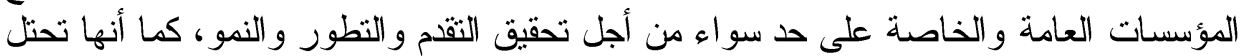

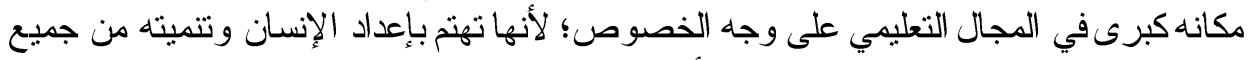
الجو انب: الجسمية والعقلية والاجتماعية والأخلاقية والنفسية؛ لكي يكون قادرا على مو اصلة حياته

العملية فيما بعد.

وظائف قيادات المدرسة الثاتوية: تشمل وظائف قيادات المدرسة الثانوية الأطر

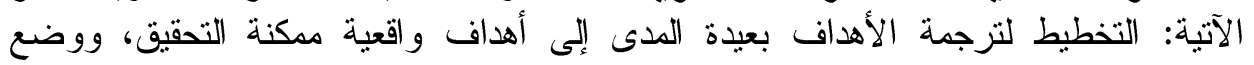

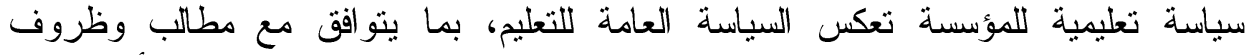

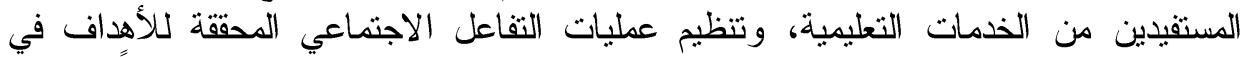

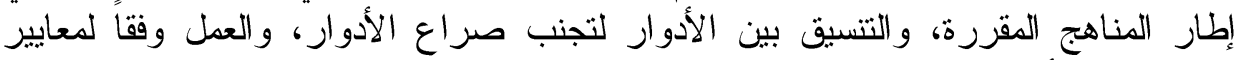

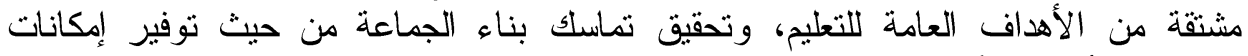

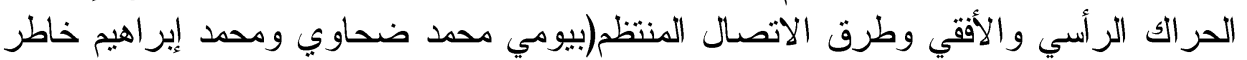

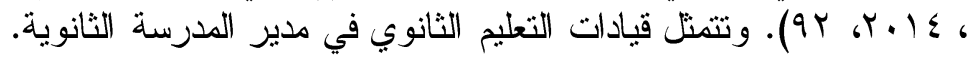

والوظيفة الرئيسة لمدير المدرسة الثانوية هى تهيئة الظروف وتقديم الخدمات التى

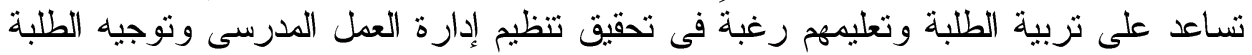
ومساعدته على التكيف وتفويض السلطة، وتقويم العملية التعليمية، ويعد مدير المدرسة القائد

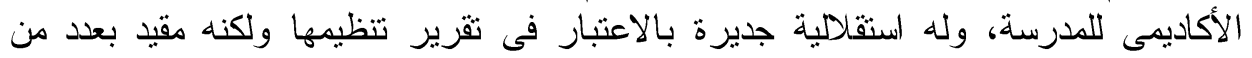

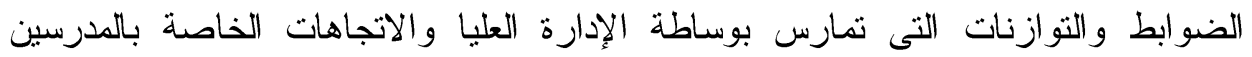
و الآباء(راتب سلامة السعيد وإبر اهيم على حسنين،

ويتضح مماسبق ان وظيفة مدير المدرسة الثانوية من أهم الوظائف فى الهيكل

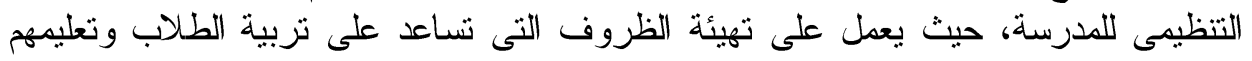
لتحقيق النمو المتكامل لهم، كما يعمل على تتمية خبرات كل من يعمل معه في المدرسة وفقا للصالح العام. 
معوقات التمكين الإداري لقيادات التعليم الثاتوي

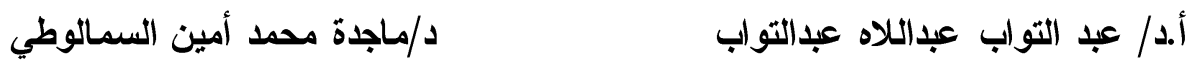

أز وفاء أحمد عبد الفتاح عامر

$=\frac{\sqrt{6}}{1 Y}$

صفات قيادات المدرسة الثانوية: يمثل مدير المدرسة الثانوية رأس العمل

التربوى بالمدرسة الثانوية، وهي ممثل السلطة ولذا تتطلب هذه التبات القيادة مجموعة من الصفات

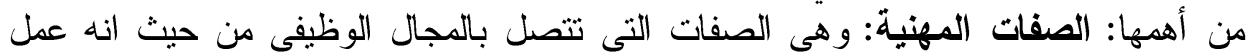

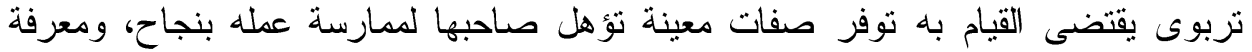

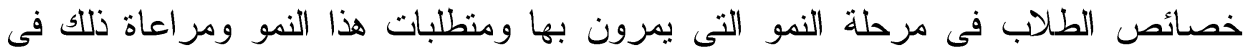

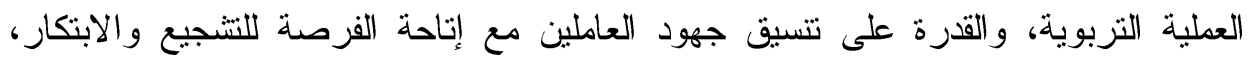

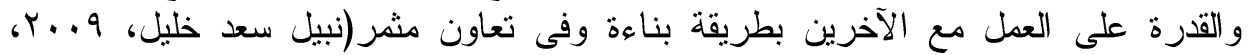
.(1) 19

الصفات الشخصية: وهى صفات تتصلٍ بالتكوين العام لمدير المدرسة الثانوية

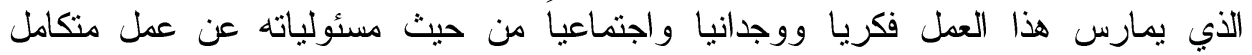

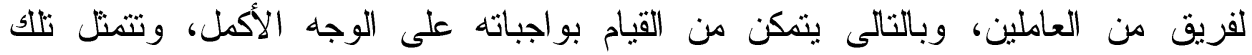

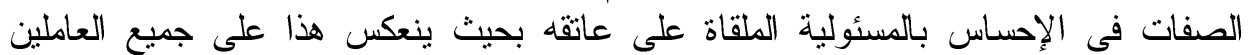

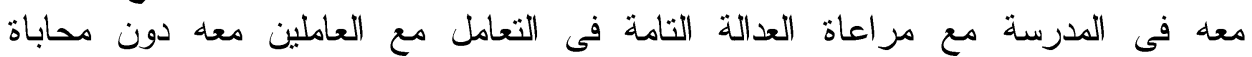

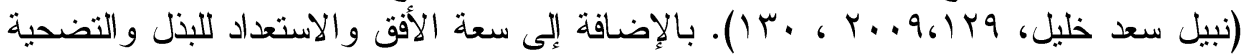

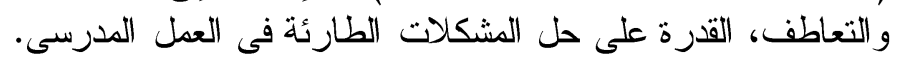

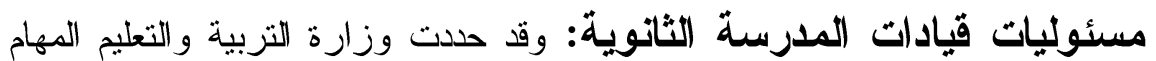

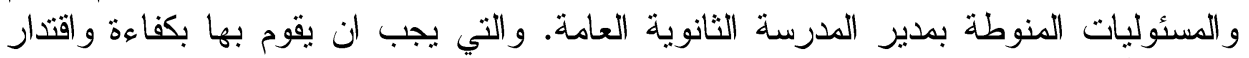

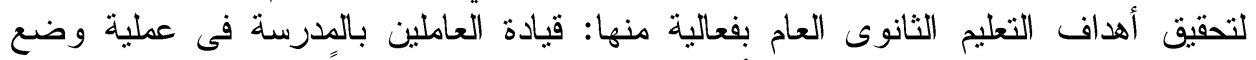
رؤية مستقبلية، نساعده فى تحديد الأهداف التعليمية وجدولتها زمنياً واختيار التهائ الإستراتيجيات

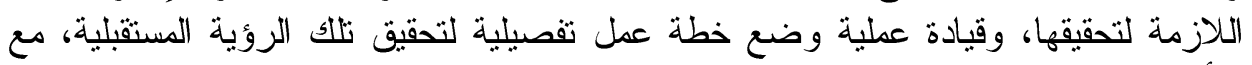

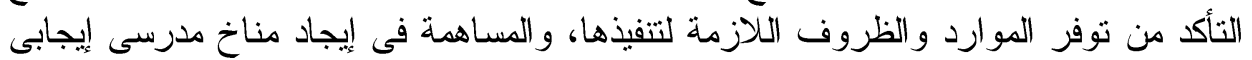

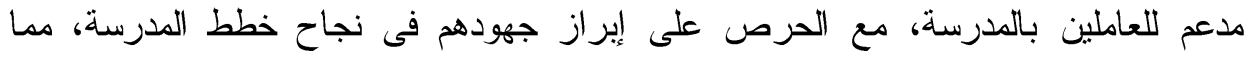

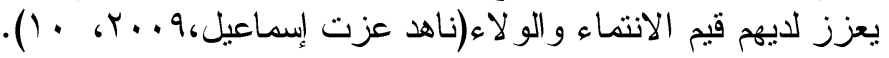

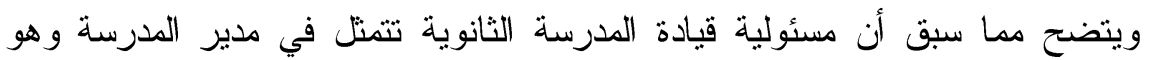
المسئول التتفيذي عن كافة الأنشطة المدرسية في المجالات التزبوية والتعليمية والثئون التئية الفنية وهية والخدمية لتحقيق الأهداف الرئيسة للمؤسسة التعليمية.

مهام مدير المدرسة وواجباته: تغير الاتجاه نحو الإدارة الددرسية نتيجة تغير وظيفة المدرسة فى المجتمع فقد أقام المجتمع الددارس بادئ الأداه الأمر وأوكل إليها تربية 


\section{المجلة التربوية لتعليم الكبار - كلية التربية -جامعة أسيوط}

$=$ (1)

أبنائه، وفهمت المدرسة وظيفتها على أنها نقل التراث الثقافى لهؤلاء الأبناء لإعدادهم

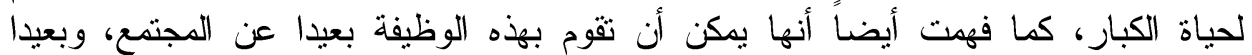

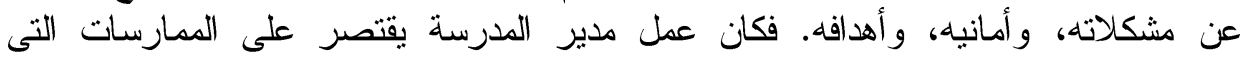
يقوم بها لتنفيذ الجوانب الإدارية وضبط النظام داخل مدرسته وتتفيذ ما يعهذ إليه من تعليمات.

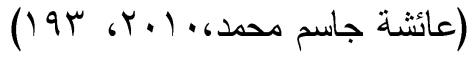

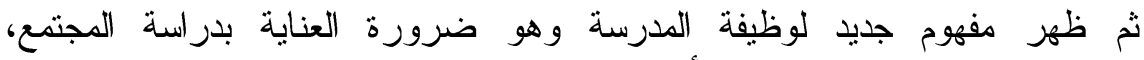

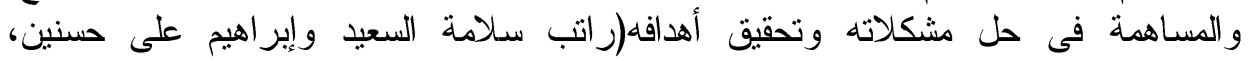
(r.17.)

المهارات التلازمة لقيادات التعليم الثانوي: هناك بعض المهارات اللازمة لقيادات التعليم الثانوي الناجحة لاتخاذ القرار الرشيد. وقد عمدت الأنظمة التربوية المتقدمة

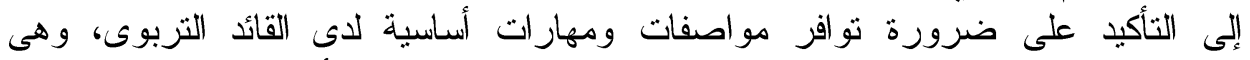

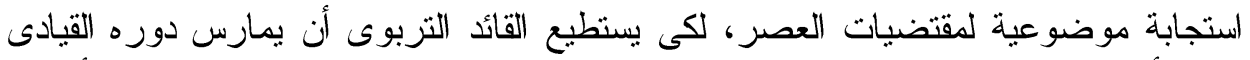

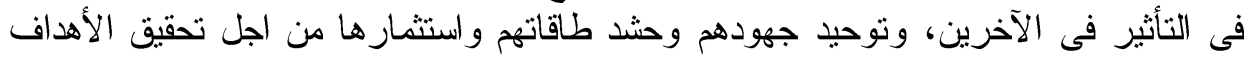
التربوية.

وتتلخص هذه المهارات فى كيفية أداء الأعمال الإدارية و المالية بكفاءة، و إتباع اللوائح

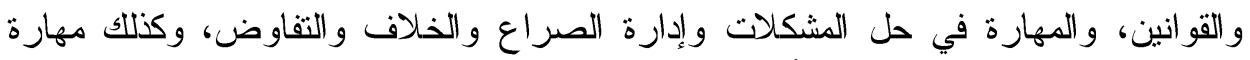

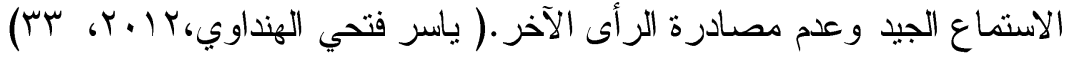

من خلال ما سبق ينبغي على قيادات التعليم الثانوي أن تكون لديها إحساس جيد بما يجب القيام به؛ لتكون إدارة فعالة توظف الإمكانات المتوفرة وتحسن استغلالها.

المحور الثالث: معوقاث التمكين الإداري لقياداث التُطيم الثانوي:

بالرغم من أهمية التمكين الإدارى فى تحسين الأداء وإثراء العمل و إعطاء مزيد من

الحرية لتحمل المسئولية لجميع المرؤوسين، إلا أنه فى كثير من الأحيان تواجه المؤسسات التعليمية العديد من المعوقات التي تحد من قدرتها على تطبيقه بالثكل الصحيح، ويمكن تصنيف هذه المعوقات كالتالى :

معوقات تثطق بالقيادات العليا للمؤسسة التعطيمية: قد تصبح أساليب القيادة

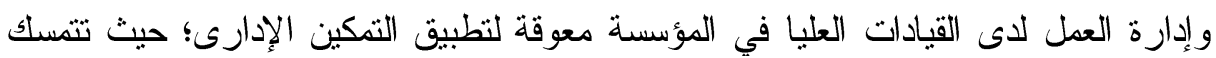
بعض القيادات باللوائح والقوانين التتظيمية المألوفة بدون استخدام المرونة عند تطبيقها وسيادة الفردية لدى البعض الآخر وقلة رغبتهم فى العمل الجماعى، وقلة تقبل وجهات النظر الأخرى مما قد يحد من تطبيق التمكين الإدارى ومن ثم مقاومة أى تغيير أو أو تطوير. 
معوقات التمكين الإداري لقيادات التعليم الثاتوي

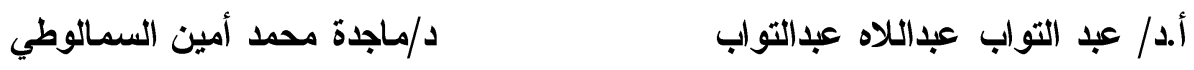

أ/ وفاء أحمد عبد الفتاح عامر

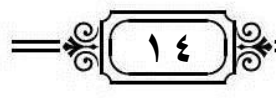

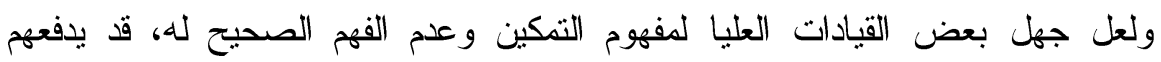

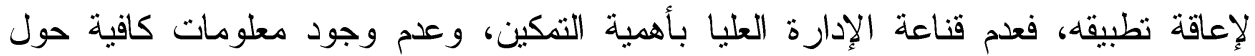

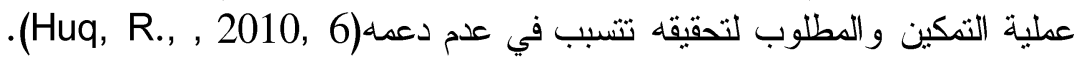

وقد تخاف القيادات النسلطية من فقدان السلطة مما يجعلهم يحجبون عن تفويضها. فقدا. لا تفوض القيادة العليا السلطة لأنها تريد الحفاظ على السيطرة العحكمة على العمليات المسندة

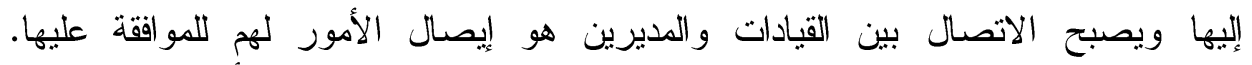

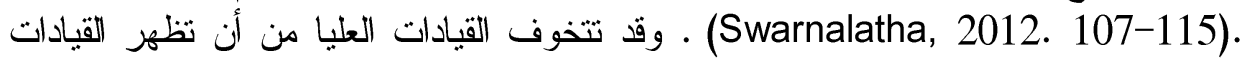
التتفيذية كفاءة فى أعمالهم أكبر من كفاءتهم مما يؤثر على تقة الإدارة بهم.

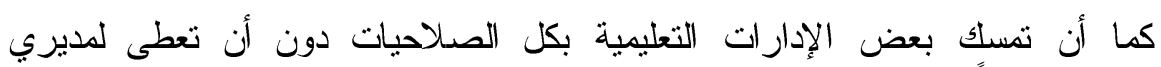

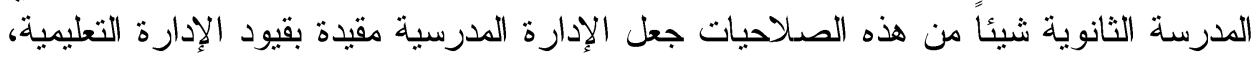

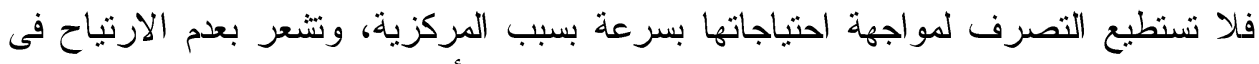

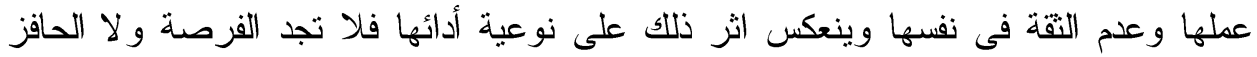

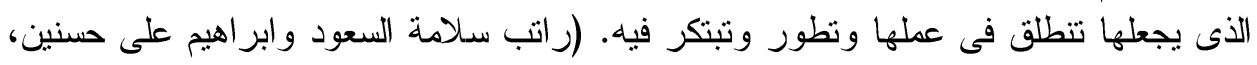

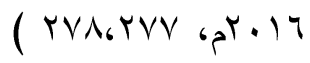

معوقات تتعلق بقيادات التعليم الثانوي: قد يرجع ضعف بعض بعض قيادات التعليم

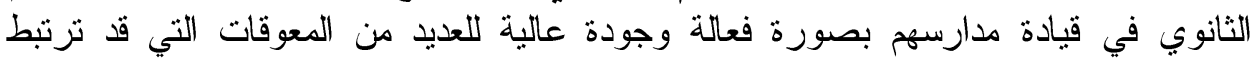

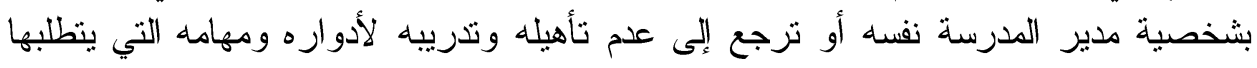
تمكينه الإداري.

فعامل الخوف لدى القادة و المرؤوسين من أهم عوامل الإعاقة لنطبيق التككين، وتتمنل

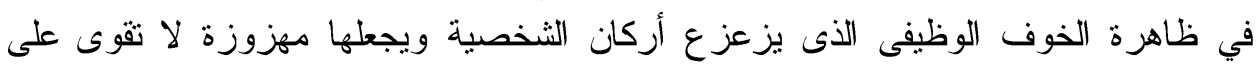

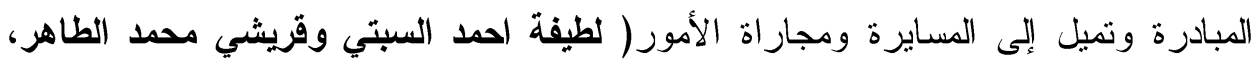
. (0. $6 \cdot 10$

وقد يرجع هذا لانخفاض كفاءة قيادات التعليم الثانوي وخوفهم من انكثاف أمرهم

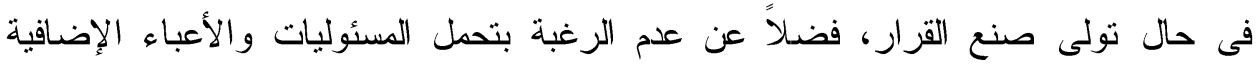

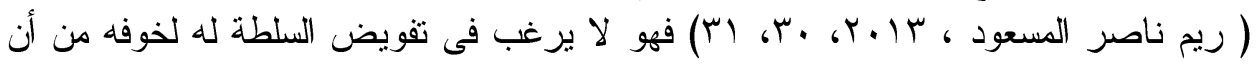




\section{المجلة التربوية لتعليم الكبار - كلية التربية -جامعة أسيوط}

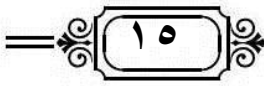

تكثف عن أوجه القصور الإدارية لديه، وقد يحدث هذا خاصة عندما يكون المدير غير كفء فى التشغيل والإجر اءات و الأساليب و الممارسات.

\section{المحور الرابع: بعض المفترحات التي يمكن من خلالها التظلب على المعوقات:}

وبالاعتماد على النتائج التي تم التوصل إليها تم وضع مجموعة من المقترحات و التوصيات تسهل تمكين قيادات التعليم الثانوي فى المؤسسات التربوية دن اهمها:

- التأهيل العلمى الكافى فى المجالين الإدارى والتريوى: فمن غير المعقول تمكين قيادات التعليم الثانوي بدون تأهيلها ببرامج تدريبية مستمرة في المجال التربوى وفى مجال القيادة و الإدارة التربوية، لملاحقة الجديد فى هذين المجالين. - التفويض والثقة الإدارية لقيادات التعليم الثاتوي:إن أساس عملية التمكين الإدارى هو الثين التقة، تقة الإدارة التعليمية بقيادات التعليم الثانوي؛ فنقة القيادة بنفسها هى من تقدة

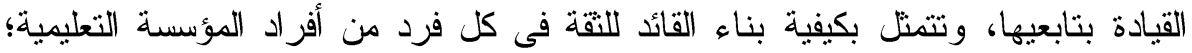
فقيادات التعليم الثانوي تعزز الثقة فى نفوس مديرى المدارس باعتناقهم لمعايير عالية تتبلور فى الرسائل والمعلومات التى يتبادلونها مع الآخرين ويطبقون تلك المعايير فى في فئي تصرفاتهم وأفعالهم لكى يكونوا قدوة للآخرين ومثلا يحتذى به فى المؤسسة التعليمية

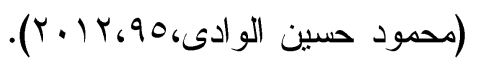

- مشاركة قيادات التعليم الثانوي فى اتخاذ القرار: تكمن عملية اتخاذ القرار الرشيد فى التى التئ تصور رجل الإدارة لنفسه كضابط لعملية اتخاذ القرار لا كصانع للقرارات فئ المؤسية التربوية، وبذلك تكون قراراته أكثر فاعلية، وكلما زادت الآراء بإثر الك قيادات التعليم

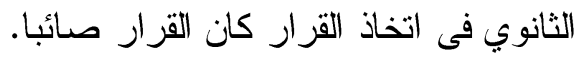

وبالرغم من قيام الإدارة التربوية باتخاذ القرارات المتعلقة بالسياسات التعليمية

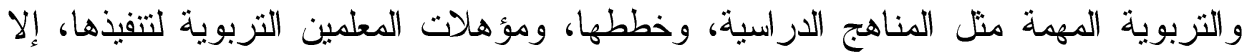
أن هذه السياسات لابد أن تستمد قراراتها بالرجوع إلى قيادات التعليم الثانوي، وأخذ التغذية الراجعة حتي لا تحدث فجوة بين التخطيط والتنفيذ فى العملية التعليمية، مما قد يؤدى بالضرورة إلى عدم تحقيق الأهداف المرسومة بالثكل المطلوب.

- الاتصال الفعال لقيادات التعليم الثاتوي مع المستويات الإدارية العليا: يعد الاتصال الفعال

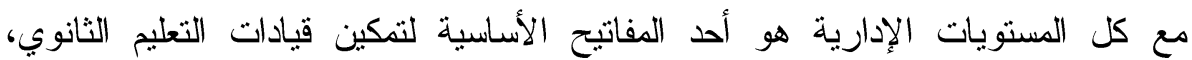


معوقات التمكين الإداري لقيادات التعليم الثاتوي

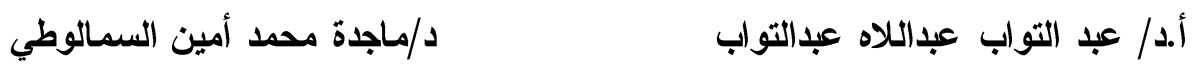

أ/ وفاء أحمد عبد الفتاح عامر

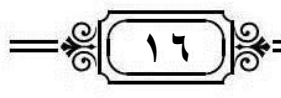

فالإدارة التعليمية لا تسنطيع حل المشكلات بمفردها لأن المعلومات المتعلقة بالمشكلة

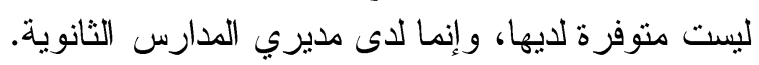

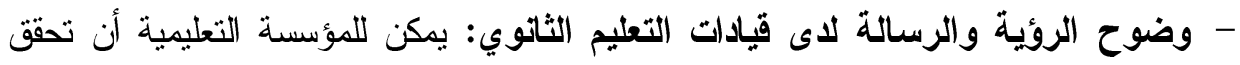

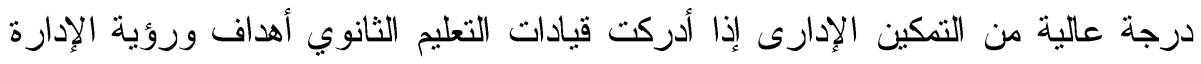

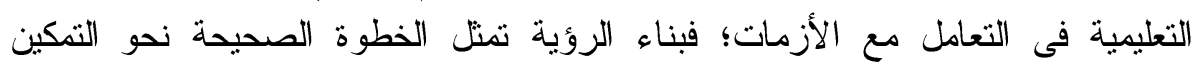

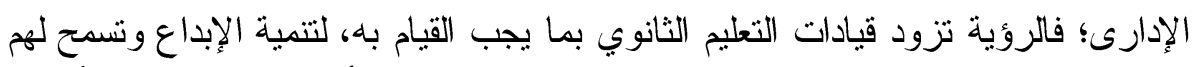

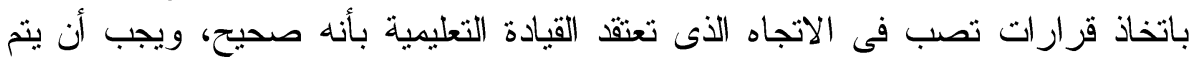

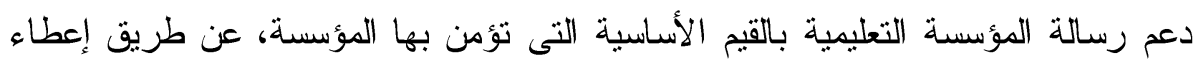

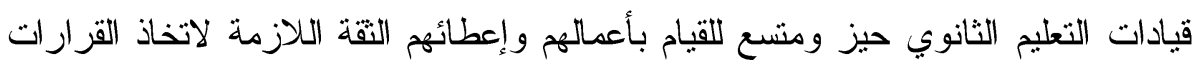
الرشيدة.

\section{تكوين قيادات التطليم الثانوي لفرق عمل لنشر ثقافة الابتكار والإبداع:}

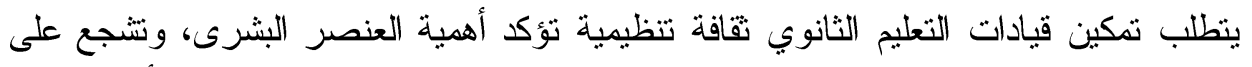

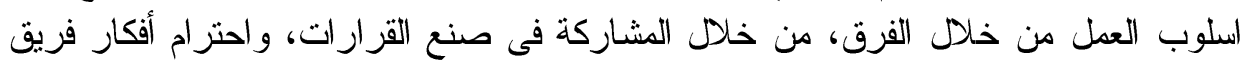

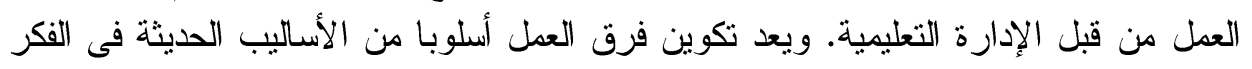

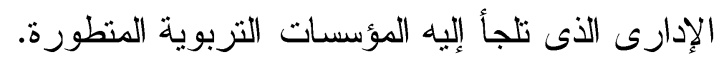

وتقوم هذه الفرق بنشر نقافة الابتكار والإبداع لضمان ظهور أكبر قدر من الأفكار

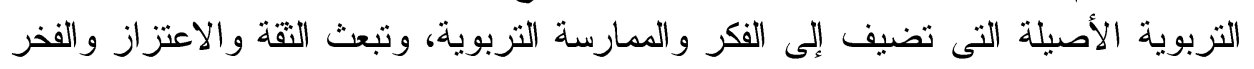

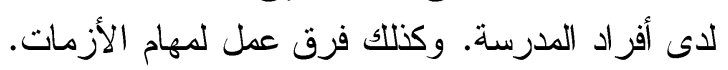

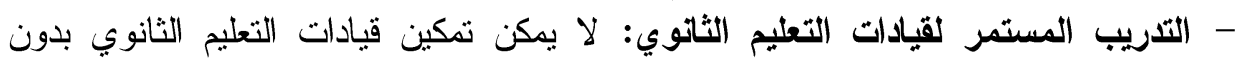

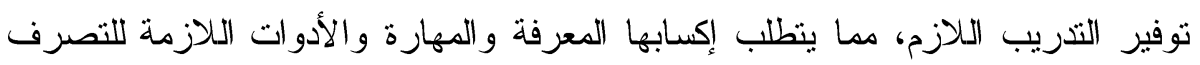
الفعال بصفة مستمرة، و التمكين الإدارى الناجح لها. 


\section{المجلة التربوية لتعليم الكبار - كلية التربية -جامعة أسيوط}

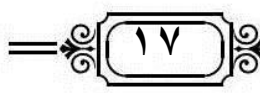

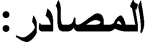

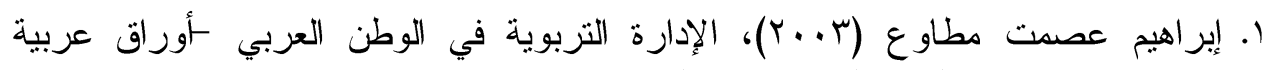

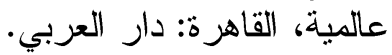

r. أحمد إسماعيل المعانى (111) و التوزيع.

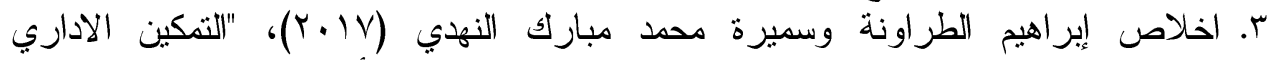

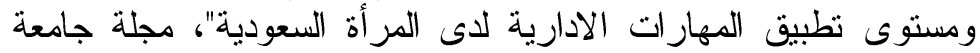

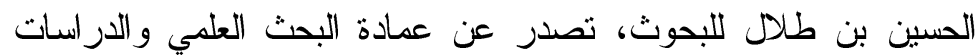

$$
\text { العليا، المجلد (ب)، العدد (1) (1). }
$$

ع. أحمد فتحي عبد الكريم(Y ( Y)، "درجة التمكين الإداري لدى القيادات التربوية من وجهة

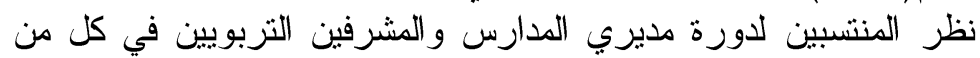

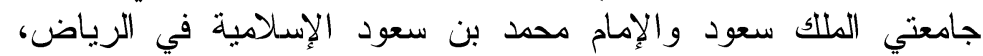
مجلة رسالة التربية وعلم التفس، تصدر عن الجمعية السعودية للعلوم

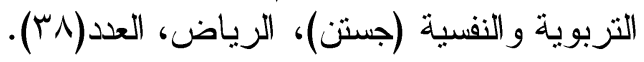

0. أسامة سعد خيري (Y Y • Y): القيادة الإدارية، عمان، الأردن، دار الراية للنشر والتوزيع. 4. السيد عليوة (1 . ب)، تتمية المهارات القيادية للمديرين الجدد، القاهرة : إيتراك للطباعة و النشر .

V. أيمن عوده المعاني وعبد الحكيم عقلة اخو ارشيدة(9 . .ب)، "التمكين الإداري وآثاره في

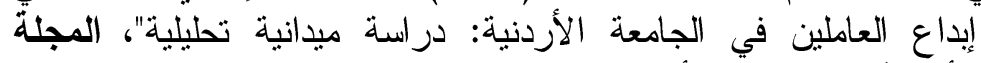

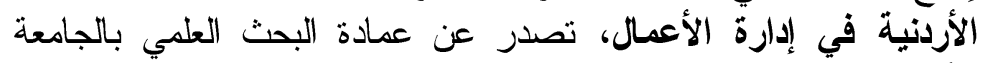

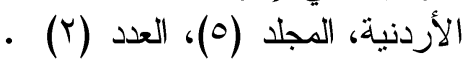

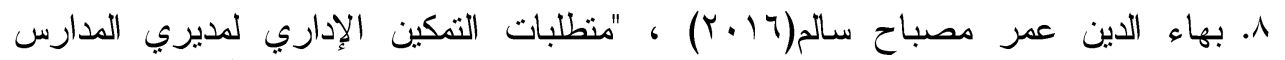

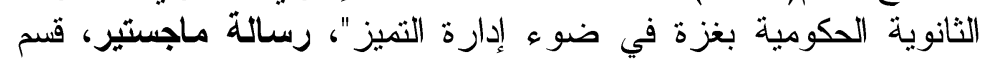

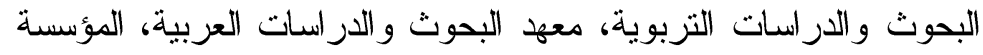
العربية للتربية و الثقافة و العلوم، جامعة الدوبة، معثول العربية.

9. بيومي محمد ضحاوي ومحمد إبر اهيم خاطر(ع ( ب):رؤى معاصرة في إدارة المؤسسات التعليمية، القاهرة: دار الفكر العربي. 
معوقات التمكين الإداري لقيادات التعليم الثاتوي

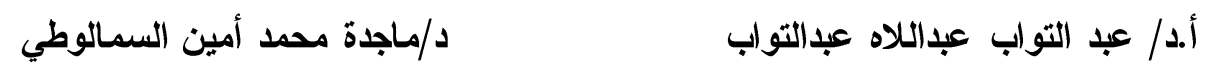

أ/ وفاء أحمد عبد الفتاح عامر

$=\frac{\mathbb{\sigma} 11}{11}$

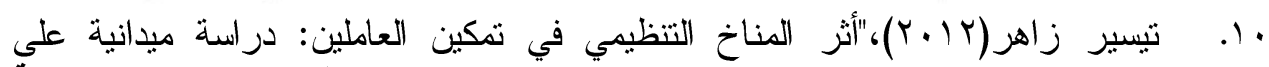

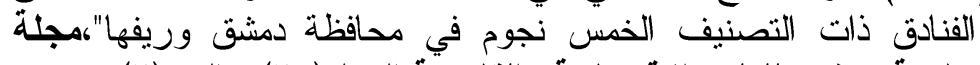

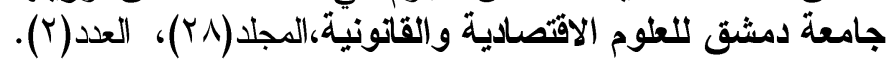

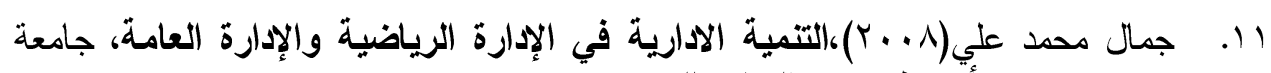

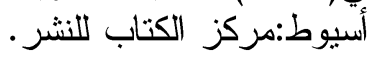

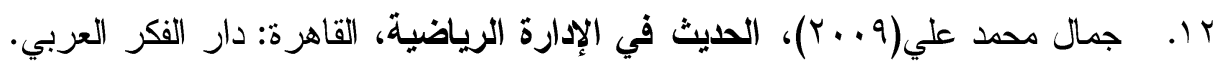

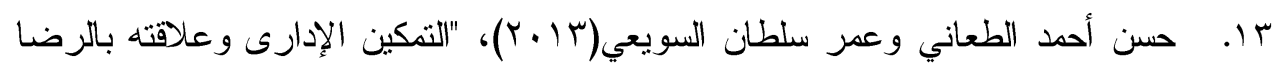

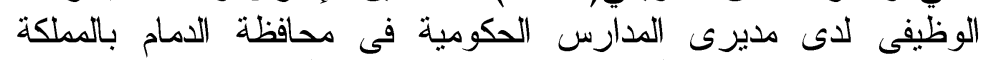

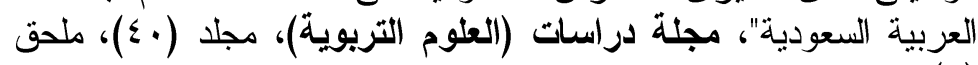

ع ا. حسين الطراونة(T . .ب)، "العلاقة بين التمكين الإداري وفاعلية عملية اتخاذ القرارات

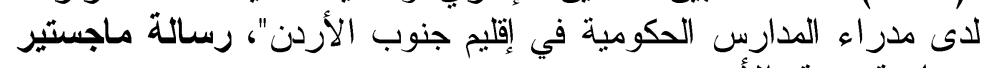

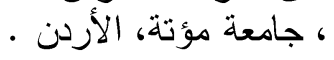

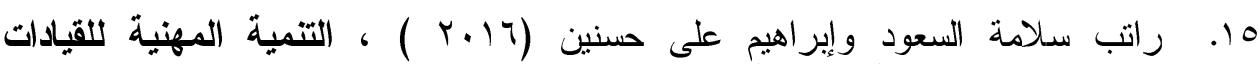

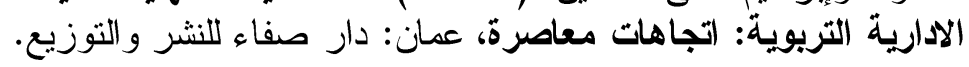

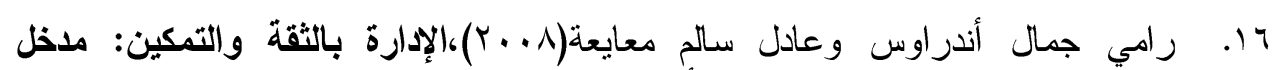

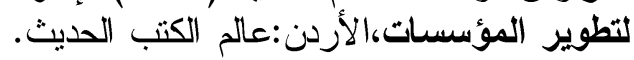

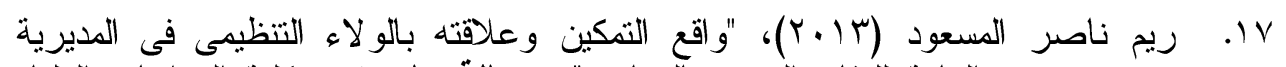

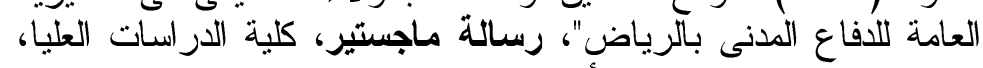
جامعة نايف العربية للعلوم الأمنية. لألرئ.

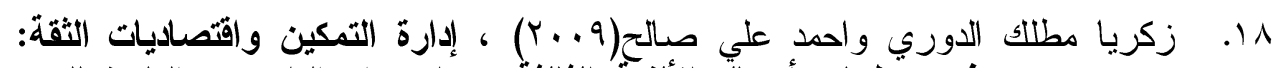

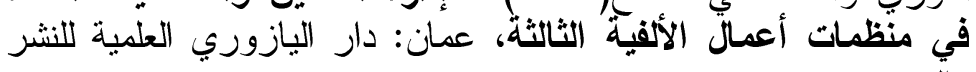

$$
\text { والتيوزيع. }
$$

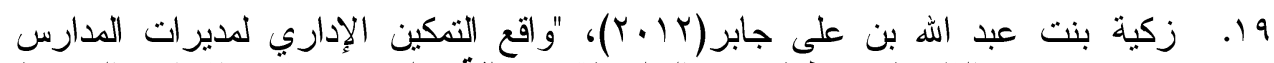

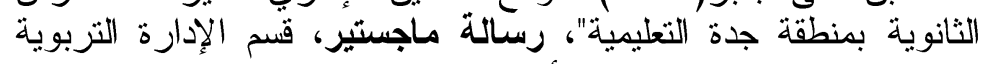

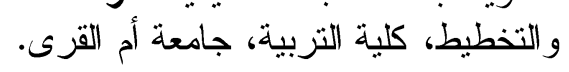

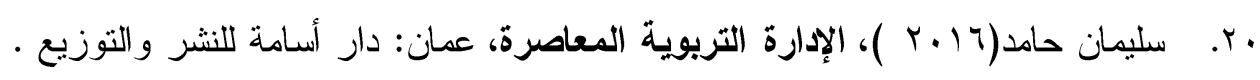




\section{المجلة التربوية لتعليم الكبار - كلية التربية -جامعة أسيوط}

\section{$=\div \frac{0}{19}$}

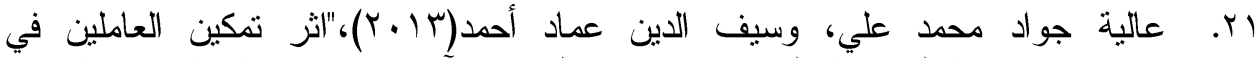
التطوير ألتنظيمي: دراسة استطلاعية لآراء عينة من العاملين في الثركة

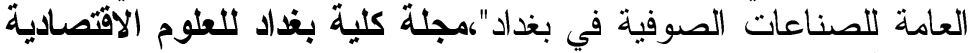

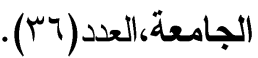

r. الإسكندرية: الدار الجامعية.

rr. لطيفة أحمد السبتي وقريشي محمد الطاهر(10 ب. أثر)، أثر التمكين الإداري في تحقيق

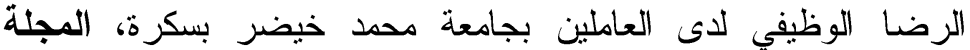

الأردنية في إدارة الأعمال، مجلد (11)، عدد (1).

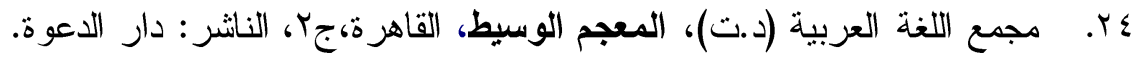

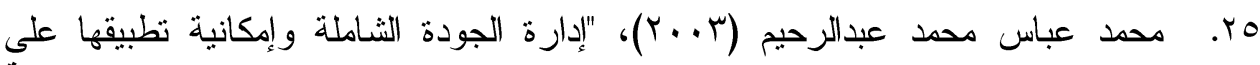

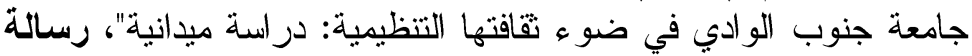
دكتوراه ، قسم اصول التربية، كلية التربية، جامعة أسيوط.

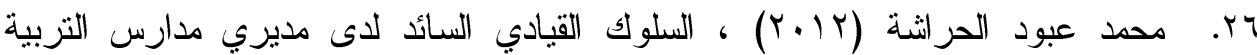

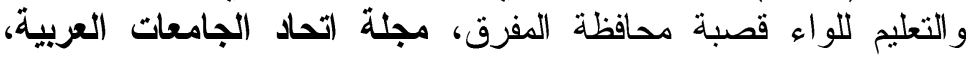

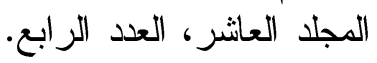

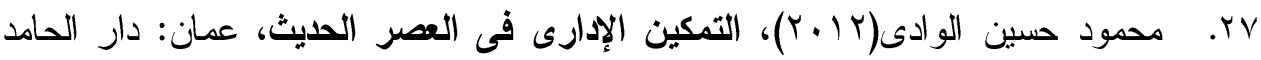
للنشر

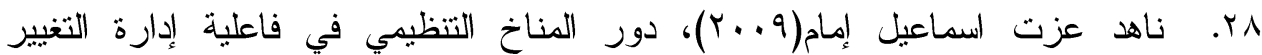

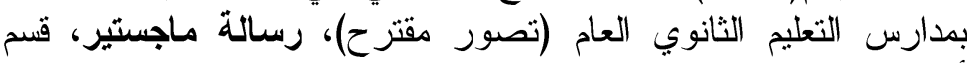
أصول التربية، كلية البنات، جامعة عين شمس.

و r. نبيل سعد خليل(q . . r )، أنماط الادارة التعليمية: أصولها وتطبيقاتها، القاهرة: دار

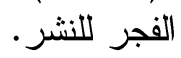

•r. نجوى حسين المسيري(با(ب)، الجديد في إدارة التعليم: الإدارة الذاتية للمدرسة: بين

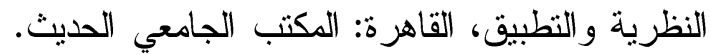

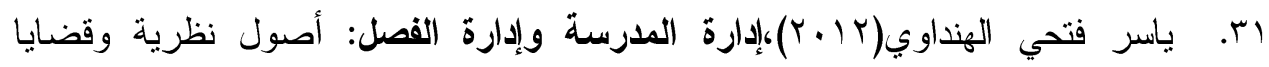
معاصرة، القاهرة: المجموعة العربية للتدريب. 


$$
\begin{aligned}
& \text { معوقات التمكين الإداري لقيادات التعليم الثاتوي }
\end{aligned}
$$

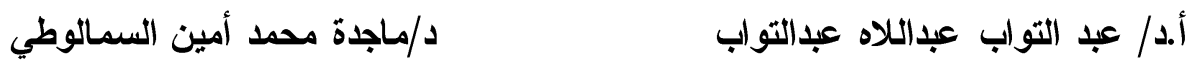

$$
\begin{aligned}
& \text { أ/ وفاء أحمد عبد الفتاح عامر }
\end{aligned}
$$$$
=r \cdot r
$$

32. Fernandez, S. \& Moldogaziev, T. (2012), "Using Employee Empowerment to Encourage, Innovative Behavior in the Public Sector", Journal of Public Administration Research and theory, Vol.23, No. 1, pp. 155-187.

33. Fook, Chan Yuen \& Sidhu, Gurnamkaur \& Britten, Linton Jerah \& Fool, Foo Say \& Kaur, Ranjit (2011). Relationship between school culture and school organizational health with psychological empowerment among secondary school principals in Malaysia International Journal of Arts \& Sciences, (16), pp. 129-143.

34. Huq, R.,( 2010) "Employee Empowerment: the rhetoric \& the reality", Axminster, Triachy Press Station Offices.

35. Ogden, S., Glaister,W. \&Marginson(2006), D., Empowerment and Accountability: Jornal of Management Studies, 43(3), 521-555.

36. Sadeghi.J and et al (2013) : "Approaches on leadership theories", journal of American science, volume 9 , number-1

37. Swarnalatha, C.I. \& Prasanna, T.S.(2012), "A study on employee empowerment to motivate the employees in health care industry in a private multi-specialty organization," Asian Journal Of Management Research, Vol. 3, pp. 107115 .

38. Swarnalatha, C.I. \& Prasanna, T.S.(2012), "A study on employee empowerment to motivate the employees in health care industry in a private multi-specialty organization," Asian Journal Of Management Research, Vol. 3, pp. 107-115. 
المجلة التريوية لتعليم الكبار - كلية التربية - جامعة أسيوط

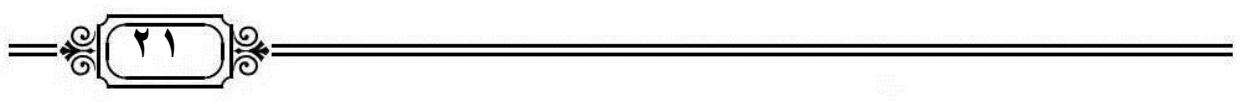

